\title{
Increasing Shielding Capabilities of Cement Mortars by Fly Ash Addition
}

\author{
IOSIF LINGVAY ${ }^{1}$, GEORGETA VELCIU1, DANIEL LINGVAY ${ }^{2}$, ADRIANA MARIANA BORS ${ }^{3 *}$, ADRIANA MOANTA ${ }^{4}$ \\ 1.National Institute for Research and Development in Electrical Engineering INCDIE ICPE-CA, 313, Splaiul Unirii, 030138, Bucharest, \\ Romania \\ 2.Sapientia Hungarian University of Transylvania, Faculty of Sciences and Arts, 4 Calea Turzii , 400193, Cluj Napoca, Romania \\ 3.ICPE SA, 313 Splaiul Unirii, 030138, Bucharest, Romania \\ ${ }^{4}$ SC CEPROCIM SA, 6 Preciziei, 062203, Bucharest, Romania
}

\begin{abstract}
The magnetic and dielectric behavior of Portland cement mortars with various fly ashes (waste from the thermoelectric power plant) with a $\mathrm{Fe}_{2} \mathrm{O}_{3}$ content of $13.8 \%$ was studied. The dielectric losses, tg $\delta$, the real component of the dielectric permeability, $\varepsilon^{\prime}$, and the real magnet permeability, i, the parameters with which we calculated the shielding coefficients, $\alpha$, of the investigated samples, have been determined for the purpose of determining the screening capacity of the investigated samples by magnetic and dielectric spectroscopy in the $50 \mathrm{~Hz}-3 \mathrm{kHz}$ (ELF) range. Following experimental data processing, it was found that by increasing the hematite microstructured hematite $\mathrm{Fe}_{2} \mathrm{O}_{3}$ content of mortar samples (by fly ash addition) increased shielding capacity in the ELF domain, recorded increases for shielding coefficients, $\alpha$, to an addition of up to $40 \%$ fly ash, being up to 14.5 times at $50 \mathrm{~Hz}$ and up to 21 times at $3 \mathrm{kHz}$.
\end{abstract}

Keywords: fly ash, cement mortars, ELF, constant shielding, microstructured hematite

In the perspective of sustainable development, requires the provision of healthy working and living conditions in a clean environment, the problem of neutralization of waste by reusing it becomes a priority [1-5].

A significant share of the thermal and electrical energy demand of mankind is produced by burning fuels in thermoelectric power plants.

Burning coal and biomass (such as wood) involves the formation of significant quantities of various pollutants such as gaseous pollutants, butalso solids such as fly ash, which by dispersion contributes substantially to air pollution (suspended particulates) [6-12].

In order to preventfly ash air pollution, in view of its use in various applications, many recent studies aim at the advanced characterization of fly ash [12-25].

One may notice from these studies that, due to its cavernous morphology [12,17, 18], low density and surface area, the fly ash addition in concrete and cement mortars leads to a decrease in thermal conductivity and density without significant changes in the characteristics mechanical [14, 16, 19-23].

It is also noted that the fly ash addition changes the electrical and dielectric characteristics of concrete and mortar cement [ 15,18$]$.

On the other hand, it was highlighted the high capacity of fly ash to contain oil products and phenolic pollutants from wastewater [24].

As a result of the technological developments, the electricity consumption shows a continuous trend of growth - which leads to the continuous increase of the level of environmental pollution by electromagnetic fields of anthropogenic origin (electromagnetic pollution of the environment).

Numerous studies have pointed out that, by altering the mechanism and kinetics of natural electrochemical processes [26], electromagnetic fields of anthropogenic origin have complex effects (in the vast majority of negative cases) on both living matter [27] and materials used in construction and installations [28, 29].

Electromagnetic fields effects of anthropogenic origin in the ELF (extremely low frequency) spectrum on living

\footnotetext{
* email: adrianambors@gmail.com, Phone: 0773917319
}

matter - including human snatches (depressions [30-32], leukemia incidence especially in children [32, 33], inhibition of sex hormone synthesis [34] and many others [35-38]), are particularly complex.

They cause changes into the microorganisms metabolism and can stimulate their multiplication [39-42], which leads to the acceleration of corrosion processes of metals by microbiological corrosion [43-48], the biodegradation of polymers from various installations [4954] and the degradation acceleration of reinforced concrete structures $[55,56]$.

On the other hand, through the stray currents generated, the ELF fields contribute to both the degradation acceleration of the reinforced concrete structures [56-62] as well as the corrosion acceleration of buried pipelines [63-66] and the underground power cables [67].

In the last decades, the share of reactive electric consumers, especially those operating in switching mode, has increased significantly [67-74], which leads to increased reactive powers and harmonic signals (odd multiples of industrial frequency) $[73,74]$ transited through the electrical networks. In these conditions, electromagnetic fields generated by electric lines (and operating in living and / or working spaces) are complex.

Thus, in the ELF domain over the fundamental component (at the industrial frequency), a series of harmonic components overlap (in a wide spectrum of frequencies, predominantly those up to about $3 \mathrm{kHz}$ ).

Certainly, without electricity and related transmission and distribution lines, modern life cannot be conceived, the radiation in the ELF domain being proportional to the powers transited and implicitly to the operating voltage of lines.

Reducing disturbances in the ELF domain by reducing power / operating voltage lines is not plausible (economic considerations) [75].

In these conditions, the protection against the effects of ELF consists in the elaboration and implementation of materials with increased capability of shielding in the civil and industrial constructions (mitigation of electromagnetic disturbing fields [76-78]). 
In view of these considerations, the purpose of the paper is to evaluate the electromagnetic shielding capacity by calculating the attenuation constant á from the data of the experimental determinations obtained by magnetic measurements and dielectric spectroscopy performed on samples of cement mortars with various fly ash additions.

\section{Experimental part}

For the comparative assessment of the shielding capacity of cement mortars with various flay ash additions (between 0 and $40 \%$ ), were prepared (as described in [18]) samples with parallel planes faces of parallelepiped shaped having the dimensions $5 \times 5 \times 2 \mathrm{~cm}$.

The cement used was Portland, CEM I grade I quality, according to SR EN 197-1: 2011. The river sand used was washed and sifted (0-2 $\mathrm{mm}$ ) with a $\mathrm{SiO}_{2}$ content of over $90 \%$. Fly ash was collected from the thermo electric power plant from Govora (Romania) and had a grain size of less than $0.5 \mathrm{~mm}$ ( $95 \%$ fraction with $<0.1 \mathrm{~mm}$ diameter).

By the X-ray fluorescence spectroscopy (XRF) technique, with WDXRF-S8 Tiger equipment, determined the oxidic percentage compositions of both fly ash and mortar samples obtained.

The dielectric characteristics of the mortar samples were determined in the $50 \mathrm{~Hz}-3 \mathrm{kHz}$ range by dielectric spectroscopy technique with an AMTEK - 1296 Dielectric interface - Solartron Analytical.

In order to ensure good contact with the measuring electrodes, the $5 \times 5 \mathrm{~cm}$ parallel planes of the mortar samples were contacted ohmically by colloidal silver paste brushing and heat treatment for $1 / 2$ hour in a thermostat oven at $90^{\circ} \mathrm{C}$.

The magnetic characteristics determination [79] was made by the measurement scheme described in [80] with an automatic RLC impedance bridge of HP4284A - Agilent type. In order to magnetic permeability determine of the mortar samples, a $0.2 \mathrm{~mm}$ thick textolite plate was winding over which 1000 spirals of enameled copper wire of 0.2 $\mathrm{mm}$ (4 layers over a length of approx. $5 \mathrm{~cm}$ ).

Various frequencies in the ELF field $(50 \mathrm{~Hz}-3 \mathrm{kHz})$, were measured using the automatic RLC bridge but also, the inductance and coil impedance with and without the mortar samples introduced into the housing.

From the values obtained following the experimental determinations the real magnetic permeability component of each mortar sample was calculated (according to the mathematical model described in [80]).

\section{Results and discussions}

The XRF determinations results, namely the fly ash oxide composition used, and the mortar samples with various experimental fly ash contents are shown in table 1.

Analysing the data presented in Table 1 it is noted that the main ash constituents used are $\mathrm{SiO}_{2}, \mathrm{Al}_{2} \mathrm{O}_{3,}, \mathrm{Fe}_{2} \mathrm{O}_{2}$ in total of $84.63 \%$, which according to $\left[1^{2} 7^{3^{\prime}} 81\right]^{2}$ it is recommended for use in concrete and mortar. There is also a relatively high content of $\mathrm{Fe}_{2} \mathrm{O}_{3}(13.83 \%$ - higher than in cements and sands commonly used in construction).

XRD-X-ray diffraction studies on the ashes used $[12,18]$ indicated that $\mathrm{Fe}_{2} \mathrm{O}_{3}$ is found in the form of magnetic hematite described in [79]. In figure 1, the results determination by the dielectric spectroscopy, respectively evolution the dielectric loss, $\operatorname{tg} \delta$, at different frequencies in the ELF domain, are presented synthetically depending on the fly ash and $\mathrm{Fe}_{2} \mathrm{O}_{3}$ content of the investigated samples.

The shielding capacity of the materials, expressed by the shielding constant, $\boldsymbol{\alpha},[\mathrm{Np} / \mathrm{m}]$ ( $\mathrm{Np}$ is a logarithmic unit for the measurement of physical field and power quantities, such as gain and loss of electronic signals) is calculated according to the electrical characteristics and magnetic properties of materials with relation (1):

$$
\alpha=\omega \sqrt{\frac{\mu^{\prime} \epsilon^{\prime}}{2} \cdot \sqrt{1+\left(\frac{\epsilon^{\prime \prime}}{\epsilon^{\prime}}\right)^{2}}-1}
$$

in which:

$\alpha$ - the attenuation constant;

$\omega$-pulsation $(\omega=2 \pi f)$,

$\mathrm{f}$ - frequency;

$\mu$ - the real component of magnetic permeability;

\begin{tabular}{|c|c|c|c|c|c|c|c|c|c|}
\hline \multirow[b]{2}{*}{ Crt. No. } & \multirow[b]{2}{*}{$\begin{array}{l}\text { Fly } \\
\text { ash }\end{array}$} & \multicolumn{8}{|c|}{ Mortar samples (with different flay ash content) } \\
\hline & & $\begin{array}{l}\mathrm{CM}_{0} \\
(0 \%)\end{array}$ & $\begin{array}{l}\mathrm{CM}_{10} \\
(10 \%)\end{array}$ & $\begin{array}{l}\mathrm{CM}_{15} \\
(\mathbf{1 5} \%)\end{array}$ & $\begin{array}{l}\mathrm{CM}_{20} \\
(20 \%)\end{array}$ & $\begin{array}{l}\mathrm{CM}_{25} \\
(\mathbf{2 5} \%)\end{array}$ & $\begin{array}{l}\mathrm{CM}_{30} \\
(30 \%)\end{array}$ & $\begin{array}{l}\mathrm{CM}_{35} \\
(35 \%)\end{array}$ & $\begin{array}{l}\mathrm{CM}_{40} \\
(40 \%)\end{array}$ \\
\hline Oxides & & & & & Conten & & & & \\
\hline $\mathrm{SiO}_{2}$ & 52.22 & 51.11 & 51.22 & 51.28 & 51.33 & 51.39 & 51.44 & 51.50 & 51.55 \\
\hline $\mathrm{Fe}_{2} \mathrm{O}_{3}$ & 13.83 & 3.80 & 4.80 & 5.31 & 5.81 & 6.31 & 6.81 & 7.31 & 7.82 \\
\hline $\mathrm{Al}_{2} \mathrm{O}_{3}$ & 18.58 & 13.14 & 13.69 & 13.95 & 14.23 & 14.50 & 14.77 & 15.04 & 15.31 \\
\hline $\mathrm{MgO}$ & 2.10 & 2.34 & 2.32 & 2.30 & 2.29 & 2.28 & 2.27 & 2.26 & 2.25 \\
\hline $\mathrm{CaO}$ & 10.45 & 27.91 & 26.17 & 25.29 & 24.42 & 23.55 & 22.67 & 21.80 & 20.93 \\
\hline $\mathrm{TiO}_{2}$ & 0.98 & 0.20 & 0.28 & 0.32 & 0.36 & 0.39 & 0.43 & 0.47 & 0.51 \\
\hline $\mathrm{MnO}$ & 0.16 & 0.03 & 0.04 & 0.05 & 0.06 & 0.06 & 0.07 & 0.07 & 0.08 \\
\hline $\mathrm{K}_{2} \mathrm{O}$ & 1.07 & 0.83 & 0.85 & 0.88 & 0.88 & 0.89 & 0.90 & 0.91 & 0.92 \\
\hline
\end{tabular}

Table 1

OXIDATION COMPOSITION OF FLY ASH USED AND MORTAR SAMPLES MADE

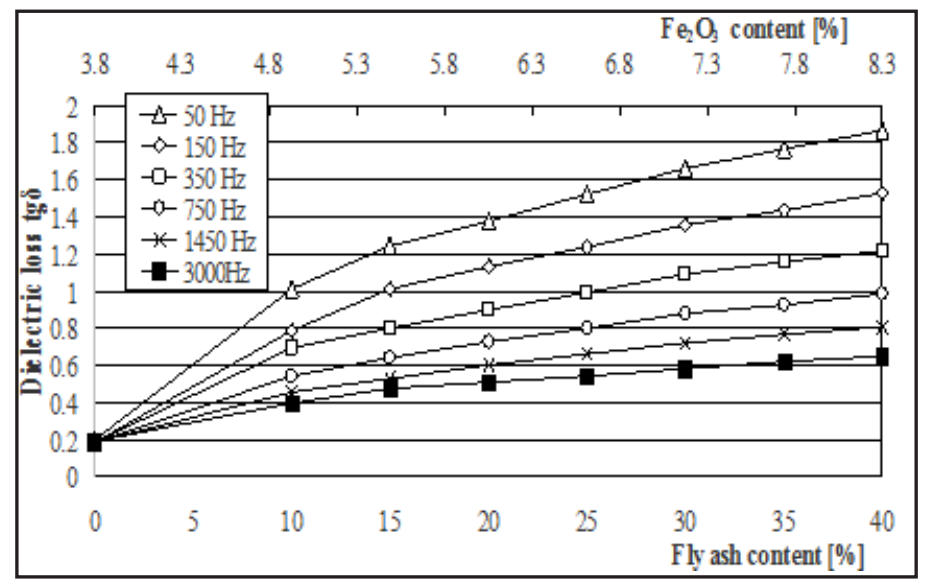

Fig. 1. The dielectric loss, $\operatorname{tg} \delta$, evolution at different frequencies depending on the content in flay ash and $\mathrm{Fe}_{2} \mathrm{O}_{3}$ of the investigated samples 


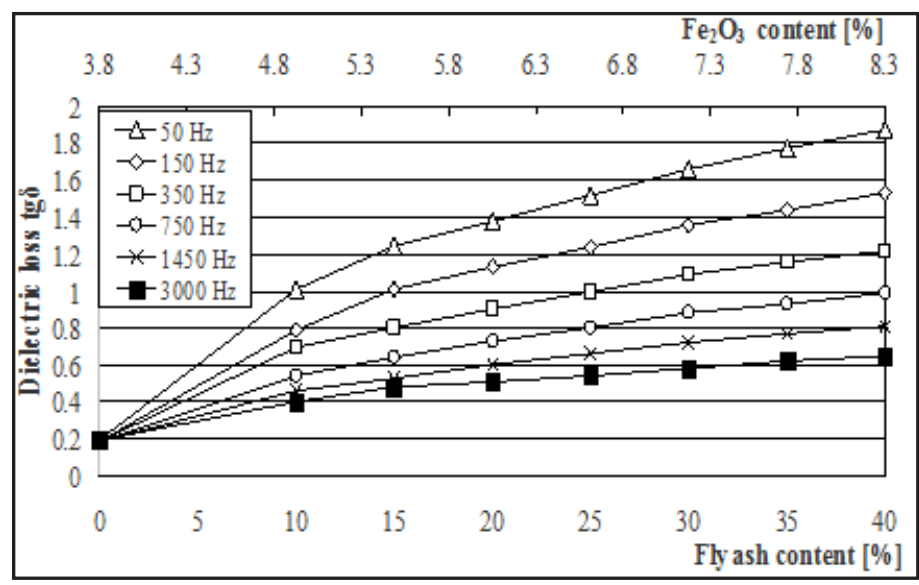

$\varepsilon^{\prime}$ - the real component of dielectric permittivity and

$\varepsilon$ "- the imaginary component of dielectric permissivity.

The relation between the imaginary componentand the real dielectric permittivity represents, $\operatorname{tg} \delta$, respectively (2):

$$
\operatorname{tg} \delta=\frac{\epsilon^{\prime}}{\epsilon^{\prime \prime}}
$$

In figure 2 the real component evolution of the dielectric permeability $\varepsilon^{\prime}$ resulting from the performed determinations by dielectric spectroscopy, is presented.

In figure 3 the magnetic determinations results, respectively the evolution at different frequencies of the applied measurement signal of the real component of the magnetic permeability, $\mu^{\prime}$, are presented, depending on the fly ash and $\mathrm{Fe}_{2} \mathrm{O}_{3}$ content of the investigated mortar samples.

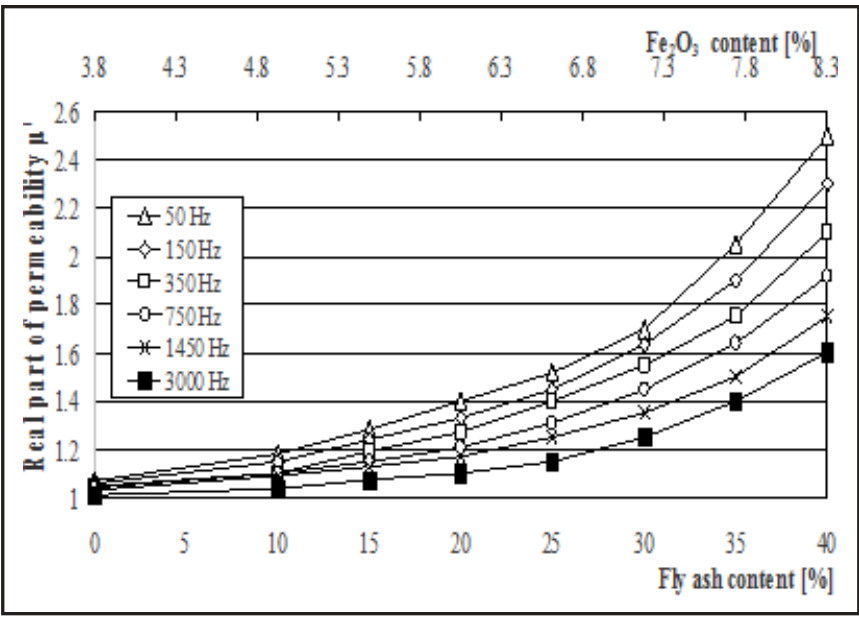

Fig. 3. Evolution $\mu^{\prime}$ at different frequencies, depending on the fly ash or $\mathrm{Fe}_{2} \mathrm{O}_{3}$ content of the investigated samples

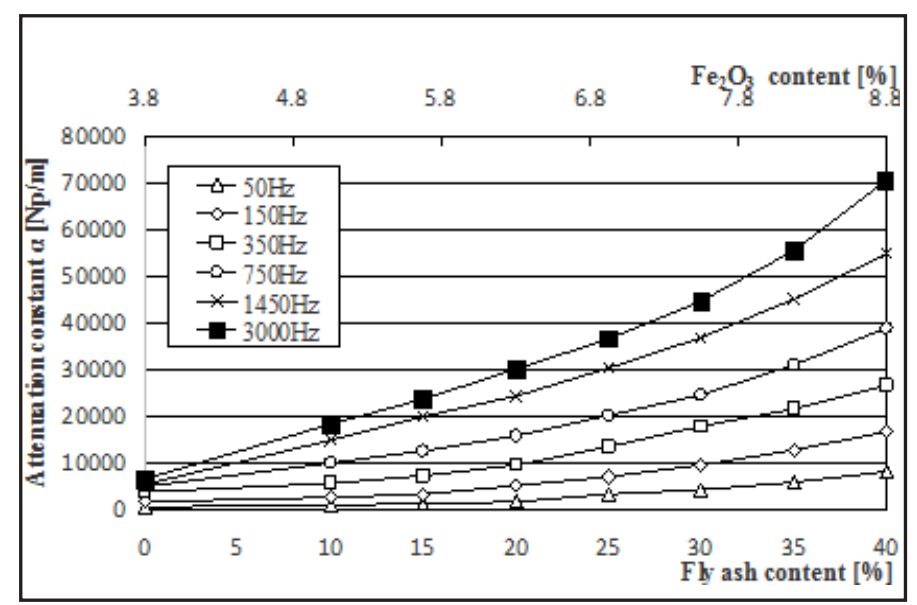

Fig. 2. The evolution, $\boldsymbol{\varepsilon}^{\prime}$, at different frequencies depending on the fly ash or $\mathrm{Fe}_{2} \mathrm{O}_{3}$ content of the investigated samples.

From (1) and (2) results (3):

$$
\alpha=\omega \sqrt{\frac{\mu^{\prime} \epsilon^{\prime}}{2} \cdot \sqrt{1+\operatorname{tg}^{2} \delta}-1}
$$

which allows - based on the data in figure 1, figure 2 and figure 3 - calculation of the attenuation constant, $\alpha$, in relation to the frequency of the measurement signal in the ELF domain (the results are presented in fig. 4).

From the analysis figure 4 it is observed that by adding up to $40 \%$ of the ash of the thermal power plant to Portland cement mortars (which, according to table 1 leads to the increase in the $\mathrm{Fe}_{2} \mathrm{O}_{3}$ content of about 2 times), the attenuation constant of the mortars in the ELF domain monotonously increases.

The increase recorded at $50 \mathrm{~Hz}$ from $531 \mathrm{~Np} / \mathrm{m}$ to 7580 $\mathrm{Np} / \mathrm{m}$ is approx. 14.5 times, and at $3 \mathrm{kHz}$ (the $60^{\text {th }}$ harmonic of industrial frequency $50 \mathrm{~Hz}$ ) the increase is from 3168 $\mathrm{Np} / \mathrm{m}$ to $66264 \mathrm{~Np} / \mathrm{m}$, that is approx. 21 times.

In figure 5 . The evolution of the frequency $m$ attenuation constant at different fly ash concentrations in the investigated mortar samples is presented.

By the comparative analysis of the figure 4 and figure 5 , in correlation with the data from table 1 , it is observed that by the addition of ash from thermal power plants (hazardous waste resulting from thermoelectric power plants) in concrete and mortar of Portland cement there more beneficial effects are obtained for the environment and the quality of life, namely:

-reducing the specific consumption of cement in construction (particularly energy-intensive raw material) and implicitly substantial energy savings with the noxious related emissions into the atmosphere - including $\mathrm{CO}_{2}$;

-the recovery of ash from thermoelectric power plants and its blocking in concrete and mortars, thus reducing the costs of ash treatment and storage as well as air ash (fly ash) air pollution;

-decrease of thermal conductivity of mortars and concrete and implicitly reduction of the energy consumption necessary for thermal comfort [18];

Fig. 4. The shielding constant evolution, $\alpha$, at different frequencies depending on the fly ash and $\mathrm{Fe}_{2} \mathrm{O}_{3}$ content of the investigated mortar samples 


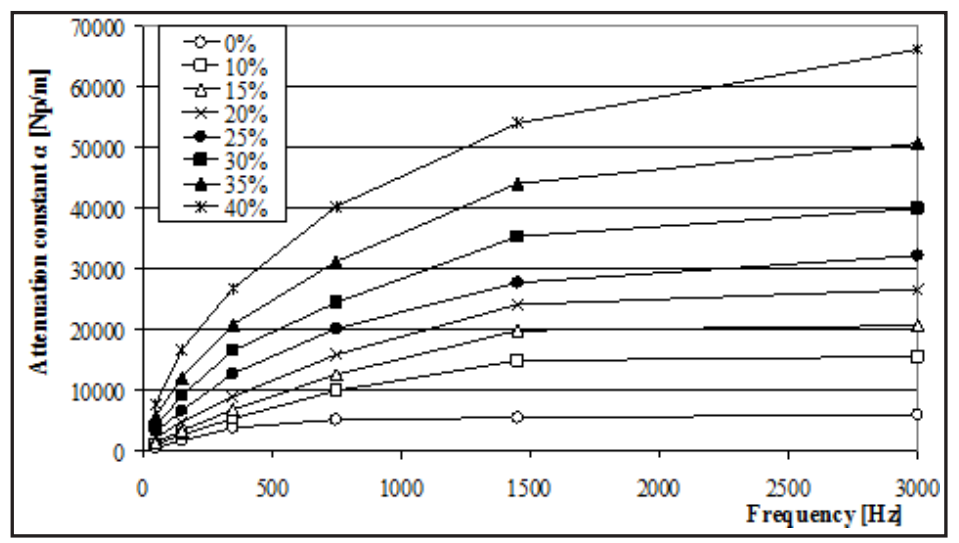

Fig. 5. The mitigation constant evolution, $\boldsymbol{\alpha}$, frequency function at different fly ash concentrations

-substantial increase in the shielding capacity, especially in the ELF domain, of the buildings walls destined for human habitat (living spaces, offices, etc.) and implicitly the disturbing electromagnetic fields diminution with negative effects on the quality of life.

The increase in the shielding capacity of concrete and mortars by the addition of fly ash from thermoelectric power plants is explained by the relatively high content of $\mathrm{Fe}_{2} \mathrm{O}_{3}$ (microstructured hematite) - which suggests that in the case of fly ash species richer in $\mathrm{Fe}_{2} \mathrm{O}_{3}$ the shielding efficiency increases accordingly.

\section{Conclusions}

By magnetic and dielectric determinations samples of cement mortar have been characterized in the ELF domain with various fly ash additions.

Based on the values obtained for dielectric losses, $\operatorname{tg} \boldsymbol{\delta}$, the real component of the dielectric permissivity, $\boldsymbol{\varepsilon}^{\prime}$, and for the real component of the magnet permeability, $\boldsymbol{\mu}^{\prime}$, was calculated the shielding coefficient, $\boldsymbol{\alpha}$, of the investigated samples.

Following experimental data processing, an increase in shielding capacity in the ELF domain was observed by the fly ash addition to microstructured hematite $\mathrm{Fe}_{2} \mathrm{O}_{3}$ in the investigated mortar samples. This increase in shielding capacity was recorded 14.5 times at an addition of up to $40 \%$ fly ash at $50 \mathrm{~Hz}$ and up to 21 times at $3 \mathrm{kHz}$.

Acknowledgment: The work was financed by projects co-financed from the European Regional Development Fund through the Competitiveness Operational Program 2014-2020, Subsidiary contract type D, no.11384/18.06.2018 (ECO-NANO-ECO) and Subsidiary contract type $D$ Rotary system of positioning with piezoelectric motor (PHOENIX).

\section{References}

1.STERE, E.A., POPA, I., Electrotehnica, Electronica, Automatica (EEA), 65, no.1, 2017, p. 97.

2.STERE, E.A., POPA, I., Electrotehnica, Electronica, Automatica (EEA), 65, no.2, 2017, p. 163.

3.STERE, E.A., POPA, I., Electrotehnica, Electronica, Automatica (EEA), 65, no.3, 2017, p. 213.

4.STERE, E.A., POPA, I., Electrotehnica, Electronica, Automatica (EEA), 65, no.4, 2017, p 193.

5.STERE, E.A., POPA, I., Electrotehnica, Electronica, Automatica (EEA), 66, no.3, 2018, p. 125.

6.LINGVAY, I., BORS, A.-M., LINGVAY, D., BALACEANU, C.M., SZATMARI, I., MATEI, A.T., Electrotehnica, Electronica, Automatica (EEA), 65, no.4, 2017, p. 5.

7.LINGVAY, I., A.-M., BORS, LINGVAY, D., Electric Vehicles International Conference (EV), 2017, IEEE xplore 2017, p. 1, DOI:10.1109/ EV.2017.8242108

8.BORS, A.M., BALACEANU, C.M., LINGVAY, I., Electric Vehicles International Conference (EV), 2017, IEEE xplore, DOI:10.1109/ EV.2017.8242107, p. 1.

9.NEAMTU, S., BORS, A.M., STEFAN, S., Rev. Chim. (Bucharest), 58, no. 9, 2007, p. 938.

10. BORS, A.M., MEGHEA, I., NICOLESCU, A.-M., BORS, A.G., 12h International Multidisciplinary Scientific Geoconference (SGEM), Albena, Bulgaria, 2012, V, p. 891.

11.BORS, A.M., MEGHEA, A., ESEANU, D., NEAMTU, S., LESNIC M., Rev. Chim. (Bucharest), 58, no.8, 2007. p. 776.

12.VELCIU, G., MOANTA, A., SBARCEA, G., MARINESCU, V, Electrotehnica, Electronica, Automatica (EEA), 64 no. 4, 2016, p. 111. 13. BARBUTA, M. HARJA, M. BABOR, D., Romanian Journal of Materials, 2010, 40, no. 1, p. 3.

14.FENOLLERA, M., MÍGUEZ, J.L., GOICOECHEA, I., LORENZO, J., Materials (Basel), 8, no.7, 2015, p. 4457.

15.VELCIU, G., CARAMITU, A.R., MOANA, A., PINTEA, J., RADERMACHER, L., LINGVAY, I., Electrotehnica, Electronica, Automatica (EEA), 65, no.3, 2017, p. 106.

16. GHEORGHE, M., SACA, N., GHECE, F.C., PINTOI, R., RADU, L., Romanian Journal of Materials, 41, no. 3, 2011, p. 201.

17. JOSEPH, K.V., FINJIN, F., J OYSON, C., DAS, P., HEBBAR, G., International J ournal of Engineering Research \& Technology (IJERT), 2, no. 8, 2013, p.1236.

18. VELCIU, G., MARINESCU, V., MOANTA, A., RADERMACHER, L., BORS, A.M., Rev. Chim. (Bucharest), 69, no. 8, 2018, p. 2040.

19. SURYAVANSHI, A.K., SWAMY, R.N., Cement and Concrete Research, 32, 2002, p. 1783.

20. VELCIU, G., SEITAN, C., GRIGORE, F., MARINESCU, V., Romanian Journal of Materials, 42, no.3, 2012, p. 69.

21. CELIK, O., DAMCI, E., PISKIN, S., Indian J ournal of Engineering \& Material Science, 15, 2008, p. 433.

22. JOSEPH, K. V, FRANCIS, F., CHACKO, J., DAS, P., HEBBAR, G., International J ournal of Engineering Research \& Technology (IJERT), 2, no.8, 2013, p.1236.

23. BENTZ, D.P., PELTZ, M.A., DURAN-HERRERA, A., VALDEZ, P., JUÁREZ, C.A., Journal of Building Physics, 34, no.3, 2011, p. 263.

24. NOVOSELOVA, L.Y., SIROTKINA, E.E., POGADAEVA, N.I., RUSSKIKH, I.V., Solid Fuel Chemistry, 42, no. 3, 2008, p. 177.

25. ATIS, C.D., Cement and Concrete Research, 35, 2005, p. 1112.

26. LINGVAY, I., LINGVAY, C., VOINA, A., Revue Roumaine des Sciences Techniques, Electrotechnique et Energetique, 53, no. 2 bis, 2008, p. 85.

27. LINGVAY, D., BORS, A.G., BORS A.M., Electrotehnica, Electronica, Automatica (EEA), 66, no.2, 2018, p. 5.

28. LINGVAY, I., BORS, A.-M., LINGVAY, D., RADERMACHER, L., NEAGU, $V$., Electromagnetic pollution of the environment and its effects on the materials from the built-up media, Rev. Chim. (Bucharest), 69, no.12, 2018, p. 3593

29. LINGVAY, I., VOINA, A., LINGVAY, C., MATEESCU, C., Revue Roumaine des Sciences Techniques, Electrotechnique etEnergetique, 53, 2008, no. 2bis, p. 95. 
30. BALIATSAS, C., VAN KAMP, I., BOLTE, J., SCHIPPER, M., YZERMANS, J., EBRET, E., Environment International, 41, no.1, 2012, p. 15.

31. VERKASALO, P.K., KAPRIO, J., VARJ ONEN, J., ROMANOV, K., HEIKKILA, K., KOSKENVUO, M., American J ournal of Epidemiology, 146, no. 12, 1977, p. 1037.

32. KITAOKA, K., KITAMURA, M., AOI, S., SHIMIZU, N., YOSHIZAKI, K., Bioelectromagnetics, 34, no. 1, 2013, p. 43.

33. MASLANYJ, M., SIMPSON, J., ROMAN, E., SCHUZ, J., Bioelectromagnetics, 30, no. 3, 2009, pp. 183.

34. AL-AKHRAS, M.A., DARMANI, H., ELBETIEHA, A., Bioelectromagnetics, 27, no. 2, 2006, p. 127.

35. BOLTE, J.F.B., BALIATSAS, C., EIKELBOOM, T., VAN KAMP, I., Environmental Pollution, 196, 2015, p. 224.

36. SZEMERSZKY, R., ZELENA, D., BARNA, I., BARDOS, G., Brain Research Bulletin, 81, no. 1, 2010, p. 92.

37. TONGEREN, M.V., MEE, T., WHATMOUGH, P., BROAD, L., MASHLANYJ, M., ALLEN, S., MUIR, K., MCKINNEY, P., Radiation Protection Dosimetry, 108, no. 3, 2004, p. 227.

38. MICHAELIS, J., SCHUZ, J., MEINERT, R., ZEMANN, E., GRIGAT, J.P., KAATSCH, P., KALETSCH, U., MIESNER, A., BRINKMANN, K., KALKNER, W, KÄRNER, H., Epidemiology, 9, no. 1, 1998, p. 92.

39. RADU, E., LIPCINSKI, D., TANASE, N., LINGVAY, I., Electrotehnica, Electronica, Automatizari (EEA), 63, no. 3, 2015, p. 68.

40. STANCU, C., LINGVAY, M., SZATMARI, I., LINGVAY, I., 8th International Symposium on Advanced Topics, Electrical Engineering, Bucharest, Romania, 2013.

41. LINGVAY, M., STANCU, C., SZATMARI, I., LINGVAY, I., Electrotehnica, Electronica, Automatica (EEA), 61, no. 1, 2013, p. 43

42.MATEESCU, C., CARAMITU, A., MARIN, D., BUTOI, N., Electrotehnica, Electronica, Automatica (EEA), 65, no.1, 2017, p. 67.

43.RADU, E., MITREA, S., PITROI, D., VOINA, A., MOSCALIUC, $H$., LINGVAY, I., Proceedings of the International Conference DEMISEE 2016, Diagnostic of Electrical Machines and Insulating Systems in Electrical Engineering, p. 38.

44. LINGVAY, J., SZATMARI, I., PRIOTEASA, P., LINGVAY, M., TUDOSIE, L.M., Korroz. Figy., 54, no. 1, 2014, p. 15.

45. LINGVAY, J., RADU, E., MITREA, S., LINGVAY, M., UDREA, O., SZATMARI, I., Korroz. Figy., 54, no. 2, 2014, p. 40.

46.LINGVAY, I., RUS, G., STOIAN, F., LINGVAY, C., UPB Sci. Bull, Series B, 63, no. 3, 2001, p. 263.

47. SZATMÁRI, I., TUDOSIE, L.M., COJOCARU, A., LINGVAY, M., PRIOTEASA, P., VISAN, T., UPB Scientific Bulletin, 77, no. 3, 2015, pp. 91.

48.PRIOTEASA, P., LINGVAY, M., SZATMARI, I., BURUNPEA, N., LINGVAY, I., Electrotehnica, Electronica, Automatica (EEA), 62, no.2, 2014, pp. 60

49. LINGVAY, J., GROZA, C., LINGVAY, C., CSUZI, I., Korroz. Figy., 49, no. 3, 2009, p. 31

50. CARAMITU, A., BUTOI, N., RUS, T., LUCHIAN, A.M., MITREA, S., Mat. Plast., 54, no. 2, 2017, p. 331

51.BORS, A.M., BUTOI, N., CARAMITU, A.R., MARINESCU, V., LINGVAY, I., Mat. Plast., 54, no. 3, 2017, p. 447.

52.SZATMARI, I., LINGVAY, M., TUDOSIE, L., COJOCARU, A., LINGVAY I., Rev. Chim. (Bucharest), 66, no. 3, 2015, p. 304.

53.LINGVAY, J., SZATMARI, I., LINGVAY, M., TUDOSIE, L., Korroz. Figy., LIII, no. 3, 2013, p. 71.
54. LINGVAY, I., OLLERER, K., LINGVAY, C., HOMAN, C., CIOGESCU, 0., Rev. Chim. (Bucharest), 58, no. 7, 2007, p. 624.

55. OLLERER, K., LINGVAY, J., Korroz. Figy., 45, no. 4, 2005, pp. 133135.

56. LINGVAY, I., LINGVAY, C., HOMAN, C., CIOGESCU, O., Rev. Chim. (Bucharest), 57, no. 12, 2006, pp.1279.

57. RADERMACHER, L., LIPCINSKI, D., BUTOI, N., LINGVAY, D., CARAMITU, A., MARIN, D., Electrotehnicã, Electronica, Automatizari (EEA), 65, no. 2, 2017, p. 140.

58. LINGVAY, C., COJOCARU, A., VISAN, T., LINGVAY, I., UPB Scientific Bulletin, 73, no. 4, 2011, p. 143.

59. LINGVAY, I., GOMBOS, S., LINGVAY, C., KOVACS, I ., VOINITCHI, C.-

D., Rev. Chim. (Bucharest) 57, no. 5, 2006, p. 498.

60. LINGVAY, I., GABOR, M., VOINITCHI, C.-D., LINGVAY, C., Rev. Chim. (Bucharest), 57, no. 4, 2006, p. 378.

61. LINGVAY, I., Rev. Chim. (Bucharest), 57, no.3, 2006, p. 261.

62. LINGVAY, I., GABOR, M., LINGVAY, C., Rev. Chim. (Bucharest), 57, no. 2, 2006, p. 180.

63. MICU, D.D., LINGVAY, I., LINGVAY, C., CRET, L., SIMION, E., Revue Roumaine des Sciences Techniques, Electrotechnique et Energetique, 54, no. 2, 2009, p.175.

64. LINGVAY, J., Korroz. Figy., 44, no. 2, 2004, p. 49.

65. BABAGHAYOU, F., ZEGNINI, B., SEGHIER, T., Electrotehnica, Electronica, Automatica (EEA), 65, no. 4, 2017, pp. 108.

66. LINGVAY I., CALIN C., STOIAN F., BABUTANU, C., LINGVAY, C., SECRETEANU, N., Revue Romaine de Chiemi, 46, no. 2, 2001, p. 85. 67. LINGVAY I., LINGVAY, C., CIOGESCU, O., HOMAN, C., Rev. Chim. (Bucharest), 58, no.1, 2007, pp. 44.

68. MARIN, D., MITULET, A., LINGVAY, M., Electrotehnica, Electronica, Automatica (EEA), 61, no. 2, 2013, p. 58.

69. MATEI, G., LINGVAY, D., SPAFIU, P.C., TUDOSIE, L.M., Electrotehnica, Electronica, Automatica (EEA), 64, no. 4, 2016, p. 52.

70. BOURI, S., BENMANSOUR, A., Electrotehnica, Electronica, Automatica (EEA), 65, no. 2, 2017, p. 57.

71. LI, J., TIAN, M., WU, Z., LI, X., Electrotehnica, Electronica, Automatica (EEA), 66, no. 2, 2018, p. 81.

72. TIAN, M., WU, Z., LI, J., ZHAO, Y., Electrotehnica, Electronica, Automatica (EEA), 65, no. 3, 2017, p. 163.

73. CHICCO, G., POSTOLACHE, P., TOADER, C., Electric Power Systems Research, 81, no. 7, 2011, p. 1541.

74. SPAFIU, P.C., LINGVAY, D., MATEI, G., Electrotehnica, Electronica, Automatica (EEA), 65, no. 1, 2017, p. 24.

75. RAHMAN, N.A., MAHADI, W N.L., SAID, I., HUSSEIN, H., European Journal of Scientific Research, 40, no. 2, 2010. p. 189.

76. BURNETT, J., YAPING, P.D., Building and Environment, 37, no. 89, 2002. p. 769.

77. ISTENIC, M., OLSEN, R.G., IEEE Transactions on Electromagnetic Compatibility, 46, no. 2, 2004, p. 199.

78. OREN, H., MOSHE M., MOSHE N., Environmentalist, 25, no. 2-4, 2005, p. 209.

79. LIU, Q., BARRON, V., TORRENT, J., QIN, H., YU, Y., Physics of the Earth and Planetary Interiors, 183, 2010, pp. 387.

80. HOTTA, M., HAYASHI, M., NAGATA, K., ISIJ International, 50, no. 10, 2010, p. 1514.

81. *** ASTM C618 -03 - Standard Specification for Coal Fly Ash and Raw or Calcined Natural Pozzolan for Use in Concrete

Manuscript received: 2.10 .2018 